\title{
A generative design case study for UAV-based assembly and fabrication: parametric analysis and synthesis of Iranian-Islamic Muqarnas.
}

\author{
ZAMANI, E. and DOUNAS, T.
}

This author accepted manuscript is deposited under a Creative Commons Attribution Non-commercial 4.0 International (CC BY-NC) licence. This means that anyone may distribute, adapt, and build upon the work for non-commercial purposes, subject to full attribution. If you wish to use this manuscript for commercial purposes, please contact permissions@emerald.com. 


\section{A Generative Design Case Study For UAV-Based Assembly and Fabrication}

Parametric Analysis and Synthesis of Iranian-Islamic Muqarnas

Abstract. This study proposes a DfMA (Design for Manufacture and Assembly) based on unmanned aerial vehicle (UAV) and uses IranianIslamic Muqarnas as the main case study due to their geometric modularity. In Islamic architecture, different geographic regions are known to have used various design and construction methods of "Muqarnas", a type of decorated dome.

Design/Methodology/Approach. The paper presents a study on parametric analysis of the Iranian-Islamic Muqarnas and analyses its components, geometric relations and construction methods that should be considered when constructing one. This study aims to use the Muqarnas analysis as a driver to generate a DfMA basis on the UAVs and parametric fabrication. In Islamic architecture, different geographic regions use various design and construction methods of Muqarnas. There are four main parameters of the Muqarnas that define their classification; first, their three-dimensional shape, that provides volume. Second, the size of their modules is variable. Third, their own specific generative process-algorithm, and finally, the two-dimensional pattern plan that is used as a basis in the design. Thus, the authors present a global analytical study that drives a generative system to construct Muqarnas, through a careful balance of the four parameters.

Findings. This study thus presents a global analytical study that drives a generative system to construct Muqarnas, through a careful balance of four specifications. The paper reports the result of using a parametric tool, Grasshopper and parametric plugins, for creating a generative system of several types of Muqarnas. This synthetic translation aims at expanding our understanding of parametric analysis and synthesis of traditional architecture, advancing our understanding towards using parametric synthesis, with the scope to fabricate and assemble modules towards UAV-based fabrication of Muqarnas. To do so, the authors are taking advantage of their inherent repetition and recursion.

Originality/Value. In the first step, this paper reviews studies on traditional Muqarnas (both Iranian and non-Iranian) and relevant parametric approaches. In the second step, the study aims to create a general generative system for Muqarnas. The creation of a generative system for Muqarnas is driven towards the creation of three- 


\begin{abstract}
dimensional fabrication of their components so that these are assembled automatically using a swarm of UAVs. This particular drive imposes specific constraints in the parametric system, as the assembly of the final components, the authors posit, can only take place in a pick and place fashion.
\end{abstract}

Keywords: UAV, Socially and culturally sustainable architecture and urban design, Generative system, Iranian-Islamic architecture, Muqarnas, Parametric architecture

\title{
1.Introduction
}

The paper presents a study on parametric analysis of the Iranian-Islamic Muqarnas and analyses its components, geometric relations and construction methods that should be considered when constructing one. This study aims to use the Muqarnas analysis as a driver to generate a Design for Manufacture and Assembly (DfMA) basis on the UAVs and parametric fabrication.

Muqarnas are one of the most ornamented vault types, considered one of the archetypal forms of Islamic architecture. Muqarnas were invented in the early 10th century and they have changed a lot over time in terms of design and construction methods in different geographical areas, from east of Asia until Spain and west of Africa (1). Muqarnas is considered as a complex kind of decorations that initially, aim to generate three-dimensional facades involving shadow and light and create unparalleled lines, and secondly to develop more surfaces to apply more micro decorations (2).

In Islamic architecture, different geographic regions use various design and construction methods of Muqarnas. There are four main parameters of the Muqarnas that define their classification; first, their three-dimensional shape, that provides volume. Secondly, the size of their modules is variable. Third, their own specific generative process-algorithm, and finally, the 2dimensional pattern plan that is used as a basis in the design. We present thus a global analytical study that drives a generative system to construct Muqarnas, through a careful balance of the four parameters.

In the first step, this paper reviews studies on traditional Muqarnas (both Iranian and non-Iranian) and relevant parametric approaches. In the second step, the study aims to create a general generative system for Muqarnas. The creation of a generative system for Muqarnas is driven towards the creation of three-dimensional fabrication of their components so that these are assembled automatically using a swarm of UAVs. This particular drive imposes specific constraints in the parametric system, as the assembly of the final components, we posit, can only take place in a pick and place fashion. 


\section{Background}

In Iran, there are some initial examples of Muqarnas before the Arab invasion to Iran (651 AD). These examples are mostly known as decorative elements. The oldest ones are probably left from the Median era (5th century BC). Dokan Davood, Sakavand Rock Tombs and the Tomb of Davood Dokhtar can be named as oldest examples of Muqarnas in Iran. The first example of Muqarnas, which is very close to $16^{\text {th }}$ century Muqarnas, was built in the Masjid Jam-e Shiraz and belongs to the Safavid dynasty (ninth century AD). However considerable development of Iranian Muqarnas starts from the Seljuq dynasty (10th century AD). From that period until now, Muqarnas construction has continued and during the 15 th to 16 th $\mathrm{AD}$ centuries, the most complex Muqarnas in Iranian architecture had been formed (3).

One of the oldest Muqarnas studies was conducted by the astronomer and mathematician Jamshid Kashani (Al-Kashi) in the 14th and 15th century. AlKashi explains about the applied mathematics in the book Meftah-o Al-Hesab (1420). In chapter 9, Al-Kashi describes geometric rules and relations that can be used to design and construct a Muqarnas (4). The table below reviews the various viewpoints on Muqarnas from a range of sources:

\begin{tabular}{|c|c|c|}
\hline Researchers & Source & Viewpoints \\
\hline Abbas Zamani & $\begin{array}{l}\text { Muqarnas, decoration in } \\
\text { Islamic historical } \\
\text { monuments of Iran, } \\
1966\end{array}$ & $\begin{array}{l}\text { In this research, Muqarnas is divided into four categories: } \\
\text { 1. Muqarnas at concave surfaces } \\
\text { 2. Muqarnas in the quarter dome } \\
\text { 3. Muqarnas in horizontal and vertical tiers, } \\
\text { 4. beehive shape Muqarnas. } \\
\text { In each of the four cases, it has been introduced as a } \\
\text { decorative element. }\end{array}$ \\
\hline $\begin{array}{c}\text { Titus } \\
\text { Burckhardt }\end{array}$ & $\begin{array}{l}\text { The foundations of } \\
\text { Islamic art, } 1980\end{array}$ & $\begin{array}{l}\text { Muqarnas is a special phenomenon of architecture and a } \\
\text { structure to transfer the weight of the dome to its square } \\
\text { base. Muqarnas reflects celestial motion to the terrestrial. } \\
\text { (functional and aesthetic aspects) }\end{array}$ \\
\hline $\begin{array}{l}\text { Donald } \\
\text { Newton } \\
\text { Wilber }\end{array}$ & $\begin{array}{l}\text { Iranian-Islamic } \\
\text { Architecture: The } \\
\text { Ilkhanate, } 1981\end{array}$ & $\begin{array}{l}\text { Muqarnas is a decorative element, and it is defined for } \\
\text { filling a concave area or surface with two or more quarter } \\
\text { dome shapes in which each row is further forward than } \\
\text { the row below. }\end{array}$ \\
\hline $\begin{array}{c}\text { Mahdi } \\
\text { Makinejad }\end{array}$ & $\begin{array}{l}\text { Muqarnas tiling in } \\
\text { Iranian architecture, } \\
2015\end{array}$ & $\begin{array}{l}\text { At the beginning, this element had a structural role and } \\
\text { was used to fill the corners, but over time, in addition to } \\
\text { the structural function, it also took on a decorative role. }\end{array}$ \\
\hline
\end{tabular}

\subsection{Parametric Approaches}

In 2004, Takahashi classified the Muqarnas, based on their plane design (e.g. square). For example, Muqarnas in Andalusia and North Africa (called Moroccan-Andalusian Muqarnas) are known as square-shaped cells (5). This classification could not apply for Iranian-Islamic Muqarnas. Although, the 
Iranian style is also based on a two-dimensional (2D) plan, however each 2D pattern could make several different three-dimensional 3D shapes. In IranianIslamic Muqarnas, the factors in dimension $\mathrm{Z}$ can vary, but in Takahashi classification, Moroccan-Andalusian Muqarnas is characterised regardless of variance in the third dimension. Mohammad Yaghan has studied in depth in terms of regeneration Muqarnas with Computer Aided Design (CAD) systems (6) and decoding historical muqarnas patterns (7). Although these studies can be used to reconstruct the old Muqarnas, As Mohammad mentioned, his approaches cannot design new ones (8).

Nader Hamekasi has invented a parametric strategy to model the Muqarnas. His strategy is based on using the b-spline curves. In this strategy, Muqarnas 2D pattern plane is divided into its layers and transfer into the different levels, considering the concave surface behind (9).

\subsection{Muqarnas Components}

This study aims to use traditional Muqarnas as inspiration to generate parametric ones. Iranian-Islamic Muqarnas consist of different types of components where achieving a deep understanding with their modularisation would help us to redefine its structure, parametrically.

In general, Iranian-Islamic Muqarnas consist of 8 main components: Shamseh, Taseh, Toranj, Shaparak, Parak, Tee, MooshPa and Takht. Also, Muqarnas includes many other components like Madani, but these 8 components have been used more than others so far (4).

\subsection{Muqarnas Shape}

Iranian-Islamic Muqarnas can be classified into the 4 categories in terms of shape; Jolo Amadeh (means Come forward), Rooy-E-Ham Rafteh (means to overlap), Moalagh (means hanging), and Laneh Zanboori (means Beehive shape). Also, there are other types of classification of Iranian-Islamic Muqarnas, such as: based on materials, based on geometry, based on ages, etc.

1. Jolo Amadeh: This kind of Muqarnas is built by carving the stone and It has moderate stability. It's very simple geometrically and usually doesn't have any additional decoration. It has a very heavy weight and is made in the interior or exterior surfaces of the building.

2. Rooy-E-Ham Rafteh: After caving the stone, additional decorations are attached. Decorations are made of materials such as plaster, stone and brick. This type of Muqarnas is similar to the Jolo Amadeh, but with more complexity in decoration and it has moderate stability either. 
3. Moalagh: Its shape is similar to stalactites and is formed by attaching various materials such as plaster, tiles to the inside of the concave surface. This type of Muqarnas looks dangling and it doesn't have high stability.

4. Laneh Zanboori: It looks like small hives stacked on top of each other and it is similar to Moalagh. (3)

\subsection{Traditional Construction Methods}

Iranian-Islamic Muqarnas traditionally are built in three ways. There exist some other construction methods, but these three methods are most common between the traditional architects thus forming an a-typical cannon:

1. Superimposed (Barikeh-e Tagh): In this method, first, concave surfaces are built to support the Muqarnas elements. Then the elements are put on the surfaces so that there is no space between the Muqarnas and surface. In this method, the supporting surface named Posht Band that means to support from the back (10).

2. Suspended Layer (Takhteh Gachi): In this method with the help of the 2D patterns plan, patterns' cells are built in the ground then move to the different levels and combined with the architectural structure. Afterwards, each Muqarnas is attached to its relevant elements (11). In this method, there is a space between the Muqarnas and structure (10).

3. Corbeled Muqarnas (Aviz dar): In this method, Muqarnas is carved from stone or wooden blocks. The Muqarnas elements are carved from the middle of the dome (or vault) to the outlines (10).

\subsection{Muqarnas Geometry}

Decorations in Islamic architecture are inspired by Islamic philosophical concepts and mathematics play an important role to convey these concepts (12).

The oldest mathematical classification of Muqarnas has done by Jamshid Kashani (Persian astronomer and mathematician, 14th and 15th century). AlKashi divided the Muqarnas, based on the 2D pattern plan and components arrangement, into 4 categories. This classification has been used for several decades by traditional architects (13).

1. Simple Muqarnas: a kind of Muqarnas in which lines are drawn instead of curves and cells are repeated. In the 2D pattern plan, only two shapes, square and rhombus, are used. Half-square and halfrhombus might be used too. Also, all cells' sides are in the same length. 
2. Stretched Muqarnas: The height of each level of the Muqarnas could be different.

3. Curvy Muqarnas: This kind of Muqarnas looks like the simple Muqarnas in the 2D pattern. But in the three-dimensional shape, curves are also used.

4. Shirazi Muqarnas: In this type of Muqarnas, other types of polygons are used in the 2D pattern. polygons such as triangle, pentagon and hexagon, octagon, and polygonal stars.

Also, in this classification, each Muqarnas niche consists of 5 main components (14).

\section{Parametric Strategies}

In traditional Iranian architecture, 2D patterns always play the main role to design and construct a Muqarnas (13). To create a generative system, this study initially develops parametric strategies to create a 2-dimensional pattern plan (2DPP). On one hand, this 2DPP would help us to have an outline of modules 3D shapes and on the other hand, 2DPP can show us the right placing of the modules and guide us to generate assembly methods.

\subsection{Parametric 2DPP}

Several traditional patterns have been examined in terms of digitalisation and finally, the pattern Shamseh has been chosen, as it is a better fit for modular production. Although Shamseh (or Islamic star) is present in many post-Islamic historical monuments in Iran, but in this research, the twodimensional pattern of Isfahan Mosque (Masjid-i-Jame) has been analysed.

To create a parametric 2D plan inspired by Shamseh pattern that used in the Majid Jame, the idea is creating several points toward two vectors. These points will be used to create 2 polylines. $\mathrm{X}$-axis and the rotated $\mathrm{X}$-axis are used. The angle used to rotate the axis is obtained by dividing a numeric variable by 360 . The numeric variable would be the number of requested niches to have in 360 degrees. The point $0,0,0$ is used to move and create several points. To create two polylines, the last point and first point have been ignored and two polylines are created. Then with the command 'rotation', a complete pattern would be created. The number of rotations is as same as a numeric variable in 360 degrees. (Figure 1) 

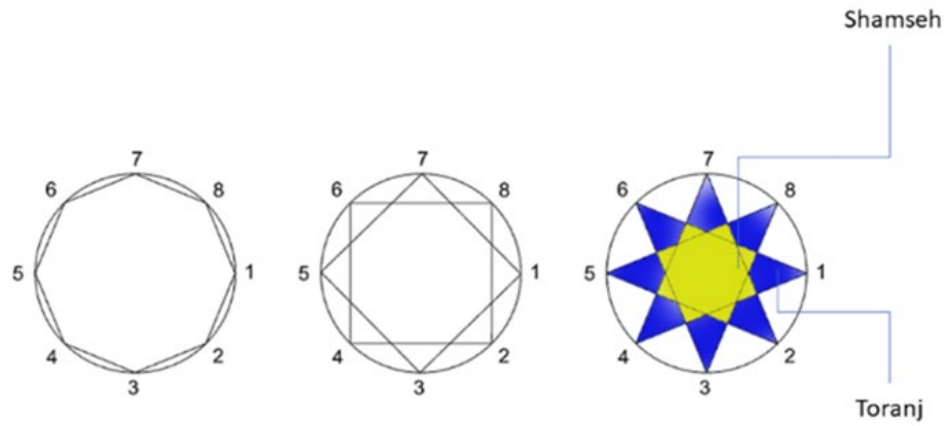

Figure 1 Islamic Star pattern is one of the most used patterns in Iranian-Islamic architecture decoration. In Persian architectural literature, Islamic star named Shamseh and each

Shamseh is surrounded by several Toranj. Credits: Erfan Zamanigoldeh

\subsection{Parametric Muqarnas}

As mentioned, several parametric strategies have been compared in terms of digitalisation procedure. To understand the procedural difference of the strategies, finding algorithm bugs and gaps, we conducted, reviewed, and compared eleven (11) parametric sketches. Advantages and disadvantages of each digital strategy, from the point of view of the fabrication feasibility and UAV based assembly, the possibility of adding joints and structure of components have been assessed. Finally, the strategy below has been selected to be used to be assembled by UAVs. (Figures 2, 3 and 4)

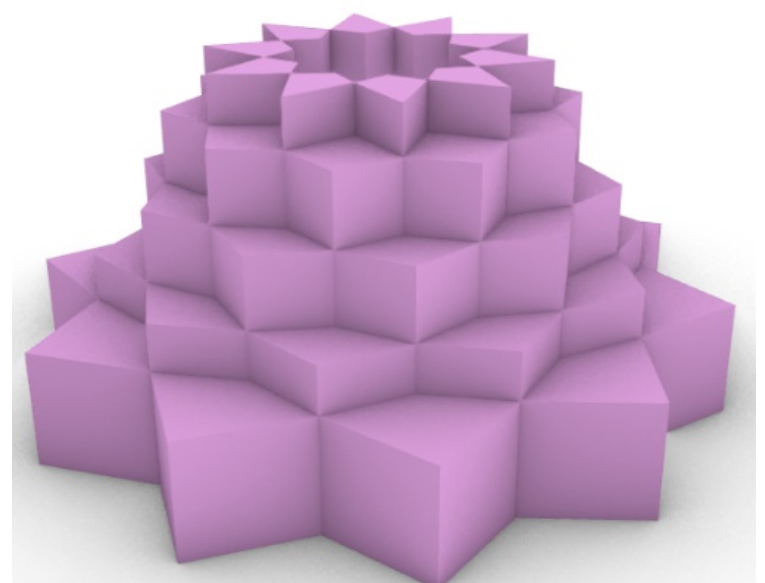

Figure 2 A complete dome made by parametric modules Credits: Erfan Zamanigoldeh 
Each module should be extracted from its specific unit in the designed parametric pattern. After creating Muqarnas pattern (and before 360-degree rotation), the units in the pattern must be separated to turn to separate surfaces. Then, the surfaces are extruded to turn to the volumes (or modules). The height of modules can be the same or vary, in this study, the same height is used. Each module transfers to its defined level. The height of the modules is used, to define the levels. For example, the height of the third floor will be the sum of the heights of the first and second floors' modules (mass addition). However, to add the joints, an overlap is needed to add between two top and bottom modules. To do so a formula has been created to specify each modules level $(2 h+10 ; h$ is the height of the modules). This formula can be changed for other types of modules or structures. After putting the modules in the appropriate levels, they should have arrayed them to have a complete dome (figure 2).

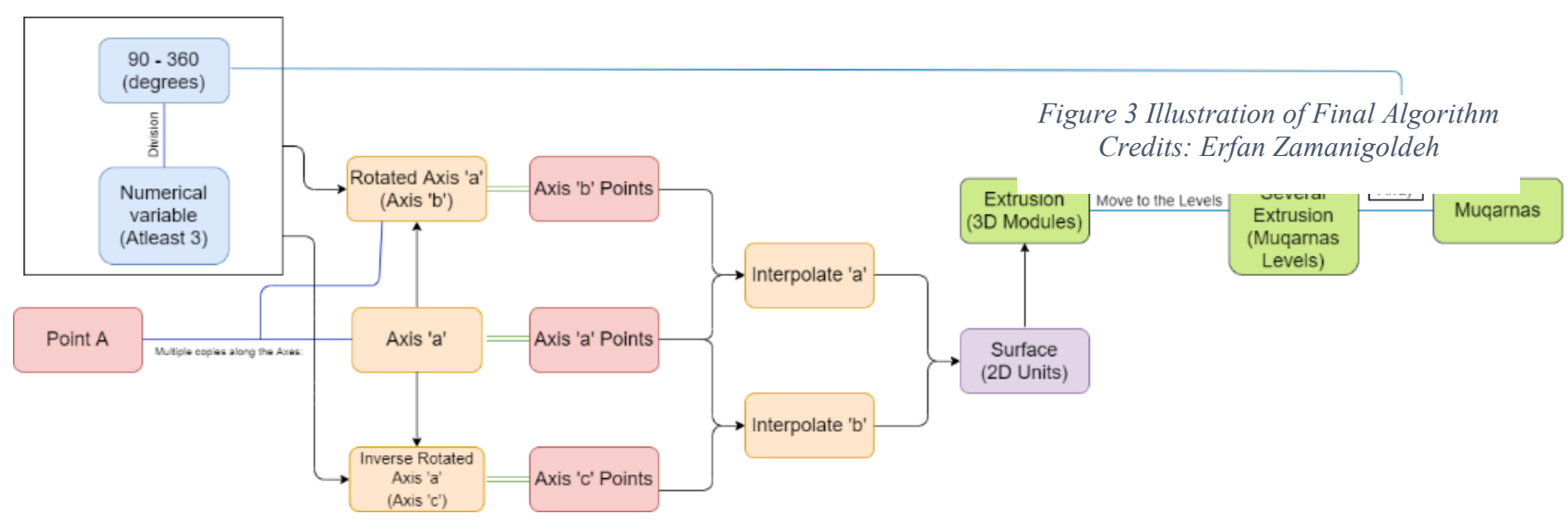

\subsection{Algorithm Parametric Design Process Overview}

In this section, all done parametric sketches have been reviewed to compare the advantages and disadvantages of each. This section has been explained to figure out challenges, algorithm bugs and gaps of the decoding process (from traditional to parametric). Factors such as joints and structural strength that would lead us toward UAV-based fabrication have also been analysed. All sketches have been done through Grasshopper parametric tool. 


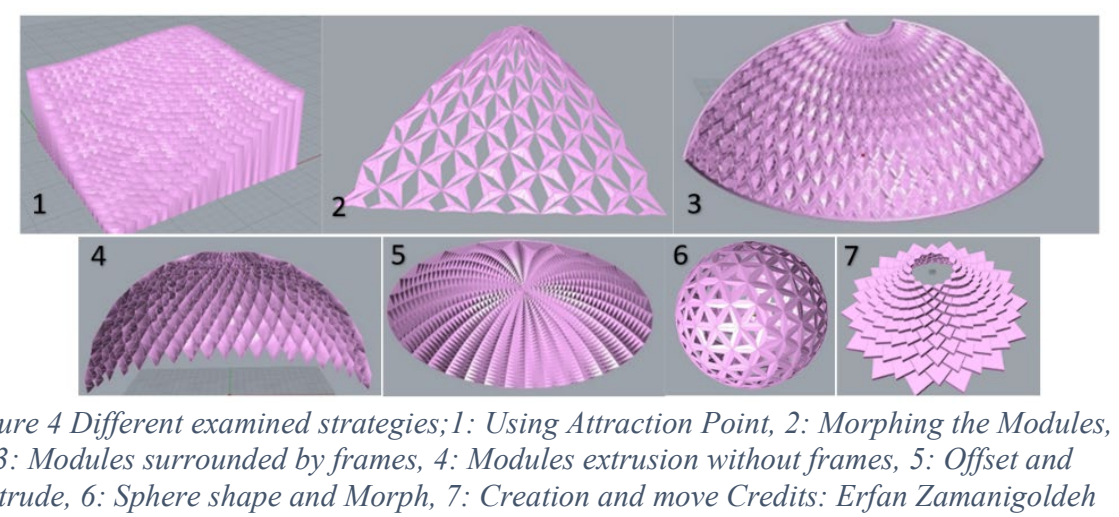

\subsubsection{Strategy 1: Using Attraction Point}

In the first glance that we look at a Muqarnas from the bottom of it, we see a circle or half circle that all components become smaller as they become closer to the centre. The idea of using 'attraction point' and surface came from this simple observation of the Muqarnas. To examine this strategy, a surface has created and divided into the same size cells.

Indeed, the archived result has not a good algorithm as it is not changeable parametrically and flexible. This algorithm would work only in the square surfaces and the size and shape of each component must be the same.

\subsubsection{Strategy 2: Morphing the components}

Before examining this strategy and other "Morphed" strategies it was thought morphing the components into a surface could raise flexibility in design. In the first attempt, a surface has been created and it has been divided into the diamond-shaped cells. Then, a pilot module has been created and was morphed into the divided cells.

Not only the algorithm is too heavy to proceed, but also it would not be possible to consider overlap to add joints to the modules. In addition, the structure does not seem stable.

\subsubsection{Strategy 3: Components surrounded by frames}

It was the first strategy that the use of Grasshopper plugins has been tried. First, a half-dome shape surface has been created and was divided into the 'hexagon shape cells' with 'Lunch box' plugin. To achieve separated components, the frames has been created around the modules. Then with 'Weaverbird' plugin the 3D modules have been created from their 2D pattern. 
As the result, the issue of the heavy algorithm is remaining and on the other hand the components are stick in design the shape and there is no space to add the joints.

\subsubsection{Strategy 4: Components without frames}

This strategy is like the previous one. The only difference is to not have frames around components.

The most obvious problem is on the bottom border of the surface. The components could not sit on the ground easily and it would affect the stability of the structure.

\subsubsection{Strategy 5: Using 'Offset surface' and 'Extrusion'}

After creating a dome shape surface, the surface divided into the square shape cells. Then small surfaces are created. After offsetting the small surfaces, the centre of them is specified and initial surfaces have been extruded into these centre points.

This strategy like other strategies, there is no flexibility in changing the shape of the components. Although the modules are matched to each other sufficiently, the main challenge would be finding the solution to keep the components above and aside of each other.

\subsubsection{Strategy 6: Creating sphere and morph components}

In this strategy, another plugin has been tried. The idea of this strategy is to build a complete Sphere and turn it into the dome afterwards with the help of the plugins 'Graphic static', and 'ICO Sphere'. ICO Sphere is already divided into the small surfaces and it helps to reduce the parametric definitions. In the next step, the modules should be applied into the sphere.

The idea of using a complete Sphere and make it to a dome might not work. The algorithm is so heavy, and it would not be possible to do the same parametric algorithm to any kind of computers. Also, if we want to trim the sphere, the components that take place in the bottom of the dome (border of the surface), would not cut properly and it makes it difficult to design a good structure for the dome.

\subsubsection{Strategy 7: Create each row and move}

This is the first strategy with the idea of extracting the 3D design shape form the 2D pattern. First, as it has been discussed before, a Shmaseh (Islamic star) with surrounded Toranj should be created. After that, all Toranj around the Shamseh should be extruded. Then the set of extruded components should be extruded and moved above. This procedure should be continuing with the 
same ratio of scaling and the fixed number of the moving. As the number of repeating this action increasing, the number of levels would be increased too.

This strategy has a long algorithm, and it would not be easy to repeat it for the second time. The modules sit above each other properly and structure seems to work efficiently but the challenge would be to find a way to attach the modules horizontally in each level.

\subsubsection{Strategy 8: Column Head}

From this part, all the strategies are explained in detail on both sides of logic and definitions.

Muqarnas has been used to decorate the head of the columns as well. There are many kinds of using Muqarnas to decorate columns. The idea of using the column head is because of finding a deep understanding of how Muqarnas components work structurally. In this part, it has been tried to follow traditional construction and designing methods of column head Muqarnas and turn it to the parametric definitions.

In this strategy, it doesn't need to create the 2D pattern initially and separately. The faster way would be to create a polyline by specifying points with certain distances between them. Also, it's needed to specify an angle to create a zigzag polyline. This angle would be used to array the components as well. So, the angle could be achieved of dividing 360 degrees into the number of components that we want to have in each row (traditionally, Muqarnas includes 8,10 or 12 components in each row). This angle would be used to rotate axis $\mathrm{X}$ to achieve a new axis.

To do so, a point should be selected. the point 0.0 .0 is selected and has been copied several times in two axes. One axis is $\mathrm{X}$ and the other is rotated $\mathrm{X}$. The number of points minus one would be the number of levels $(\mathrm{N}-$ $1=$ Levels number).

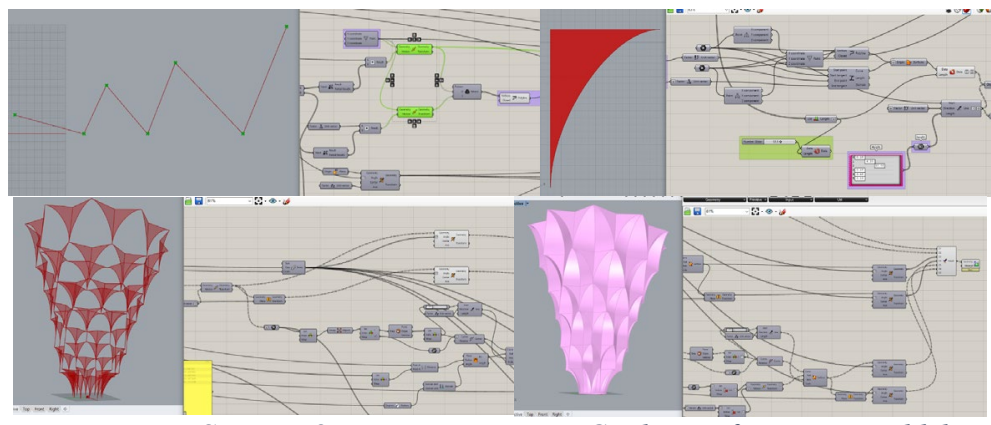

Figure 5 Strategy 8 parametric process Credits: Erfan Zamanigoldeh

Now we must add Muqarnas components. "Taseh" is used; a traditional component of Muqarnas that has been explained before. Taseh is made by "Bezier spline" component. After creating a curve, the points of it are 
extracted to made Taseh. Then Taseh should be oriented into the Polyline. To do so, Zigzag Polyline should be exploded to achieve small segments. Now it would be possible to move Taseh into the segments. It should be considered that initially, we have one Taseh and several segments, so we need to use "repeat data" component to achieve more Taseh. The input of number in "repeat data" component is exactly the number of the segments (the number of the levels).

Now we should move the components in the Z-dimension. Before starting it should be noticed that each component should stand above another component. The component that is near the middle should be a higher level and as we became far from the centre components have less component. It means that to achieve that I have used the mass addition component and then array it. The achieved result, in traditional Iranian architecture named Muqarnas Skeleton.

After filling the gaps between the skeleton, we can have the result. The resulted shape is fully flexible to change in height of the levels, the shape of the Taseh and decoration. But there are two main problems, first, the algorithm is too complicated and could not be applied to the other types of Muqarnas. The second problem is that the achieved components are not solid individually. If we want to add thickness to the components' surfaces, the components wouldn't be matched aside each other properly.

In the point of view of the fabrication, this strategy could be efficient if we want to produce whole of the Muqarnas but to produce each component separately, because the components are not solid, it will not work. (Figure 5)

\subsubsection{Strategy 9: create a Shmaseh (Islamic Star) and Toranj Surrounded}

The idea is to come from one of the most famous traditional IranianIslamic patterns. This pattern is named "shamseh" in Iran and known as Islamic star as well. The first step to create several points and a polyline is as same as the previous strategy.

This pattern has used several times that the most famous one is the Jame mosque (Masjid-i-Jame) in Isfahan, Iran.

In this strategy, the aim is to extract moulds from the pattern to go toward using moulds to create an entire dome. The main objective is to achieve a flexible algorithm to create a complex of moulds that different types of Muqarnas decoration can be applied.

The Muqarnas that would be extracted from this pattern usually consider as Beehive shape Muqarnas. (Figure 6) 


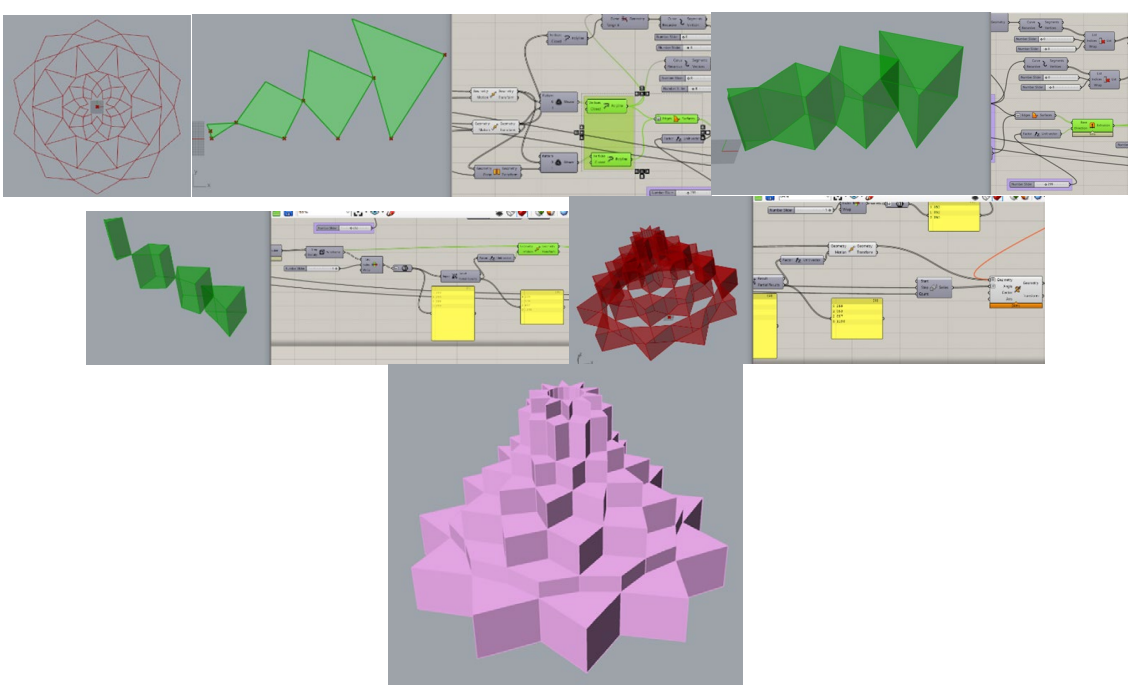

Figure 6 Strategy 9 parametric process Credits: Erfan Zamanigoldeh

In this strategy, the idea is to use the "division" component to have an angle. This angle would be the angle of the Muqarnas moulds and it's changeable parametrically. With the help of the angles, we could find several points to be used to create a base Polyline. The point $0,0,0$ could be chosen as the base point. To have an angle in Grasshopper, we use unit $\mathrm{x}$ and rotate it with the angle. Now we have two vectors: vector $\mathrm{x}$ and rotated vector $\mathrm{x}$.

To get the points, we need to move the base point $(0,0,0)$ in our two vectors. To do so, we need to specify the distances between points. These distances will be the diameter of each mould in the final design. Also, the number of points will be the number of Muqarnas levels.

To create a polyline, we use the components dispatch and weave. We shall mirror the points on the rotated vector to and repeat the polyline action to have complete cells. Then tun the cells to the surface and extrude them.

After that, the surfaces should be extruded in the z-direction. The height of moulds could not be the same for every mould, but we use the same height as it would be helpful in terms of fabrication feasibility.

To move the molds in the right direction, we need to extract the height of the molds. To do so we use Brep wireframe and use list item to extract the height of each mould. Then we can use mass addition to move each mould in the right direction.

Now it's needed to rotate the moulds. The result is not a complete dome. To complete the gaps, it needed the same action with the same pattern. So, we can use the first pattern that has created and use the "mirror" component to have a new pattern. 
Decussate rows (in terms of to be parametric) would have two main advantages. 1.it would be possible to apply separate decoration for each row. 2. It would be possible to apply a different height that produces overlap. This overlap is helpful to apply joints.

\subsubsection{Results}

The results and procedures of the other 9 designed algorithms have been used to design the final algorithm introduced in the section '3.2. Parametric Muqarnas'.

In the table below, there are a brief description and comparison between all 11 strategies. This classification would help to refine a deep understanding of the procedural difference of the exploration of 11 strategies. The strategies design procedure was helpful to refine and develop the algorithms.

\begin{tabular}{|c|c|c|c|}
\hline Strategy & Image & Achievement & $\begin{array}{l}\text { Advantages and } \\
\text { disadvantages }\end{array}$ \\
\hline 1 & & - & $\begin{array}{c}\text { not circle shape, not } \\
\text { good control on the } \\
\text { algorithm }\end{array}$ \\
\hline 2 & & $\begin{array}{l}\text { dome with } \\
\text { morphed } \\
\text { components }\end{array}$ & $\begin{array}{c}\text { flexibility in morphed } \\
\text { components shapes, } \\
\text { up to bottom } \\
\text { procedure, not good } \\
\text { structure }\end{array}$ \\
\hline 3 & & $\begin{array}{l}\text { dome with } \\
\text { components } \\
\text { and frames }\end{array}$ & $\begin{array}{c}\text { heavy algorithm, no } \\
\text { flexibility in } \\
\text { decoration, not good } \\
\text { joints }\end{array}$ \\
\hline 4 & & $\begin{array}{l}\text { dome with } \\
\text { components }\end{array}$ & $\begin{array}{l}\text { heavy algorithm, no } \\
\text { flexibility in } \\
\text { decoration, not good } \\
\text { joints }\end{array}$ \\
\hline 5 & & $\begin{array}{l}\text { Dome with } \\
\text { components }\end{array}$ & $\begin{array}{c}\text { No flexibility in } \\
\text { decoration, no } \\
\text { volumes, not good } \\
\text { structure }\end{array}$ \\
\hline
\end{tabular}




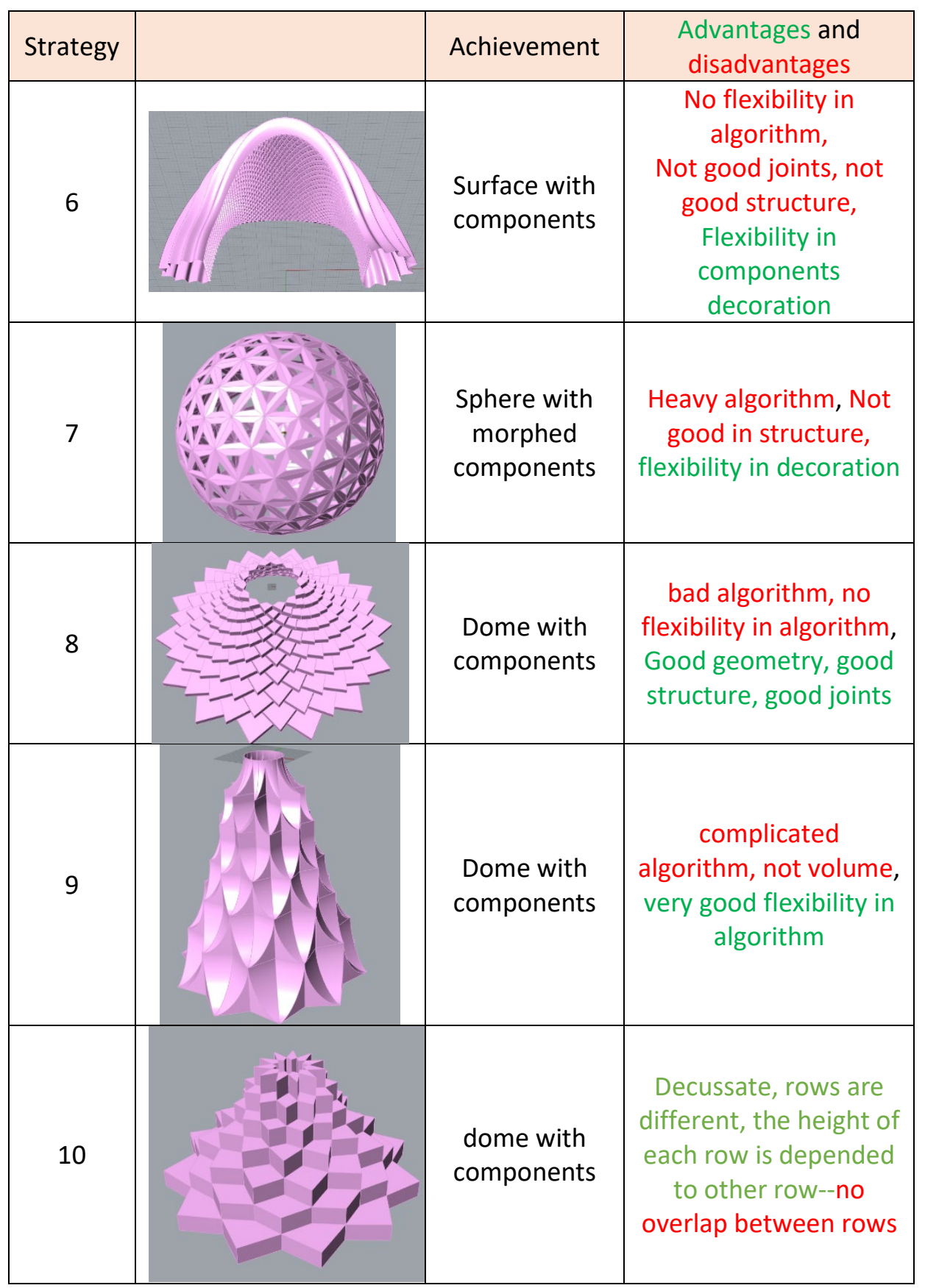




\begin{tabular}{|c|c|c|c|}
\hline Strategy & Image & Achievement & $\begin{array}{c}\text { Advantages and } \\
\text { disadvantages }\end{array}$ \\
\hline 11 & & $\begin{array}{c}\text { Dome with } \\
\text { Decussate, rows are } \\
\text { different, the height of } \\
\text { each row is NOT } \\
\text { depended to other } \\
\text { row--so we have } \\
\text { overlap between rows }\end{array}$ \\
\hline
\end{tabular}

Table 2 short brief of 11 Strategies Credits: Erfan Zamanigoldeh

\section{Structural Design}

As discussed, the Muqarnas is known as the decoration and traditionally doesn't play any structural role, but in this study, as the aim is to use Muqarnas as a vault, the structure has been optimised to have an independent Muqarnas standing on its own weight. To keep the structure and proper weight transfer, the modules are optimised in terms of joints and shape. This optimisation makes the modules spread their load to the modules below. (Figure 7)

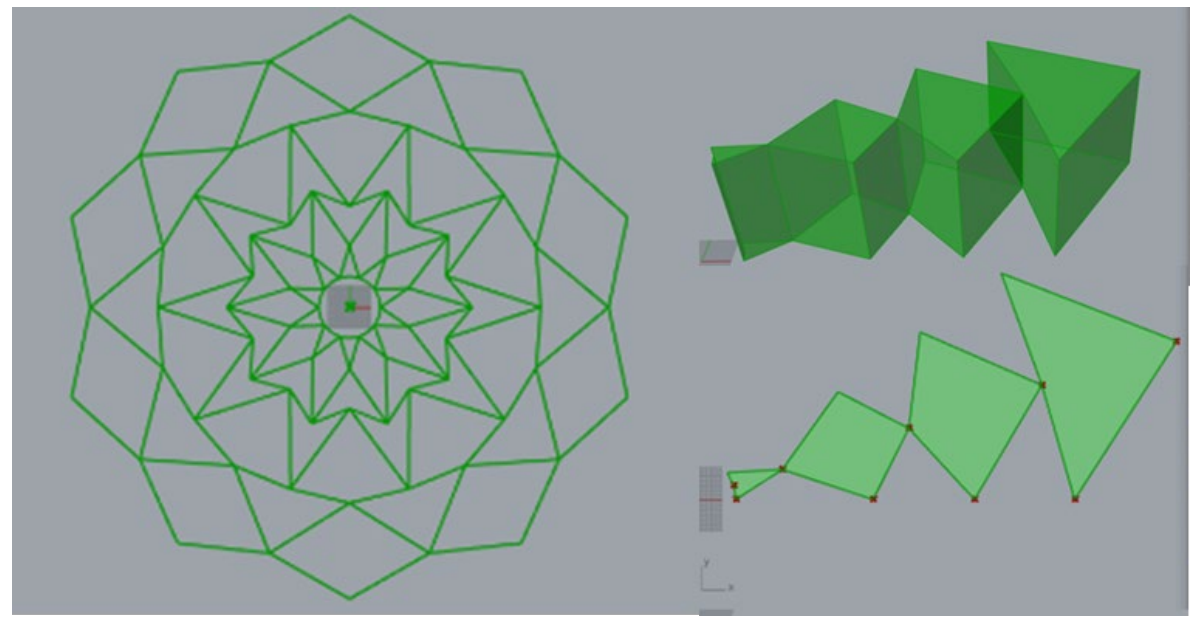

Figure 7 Each mould should be extracted from its specific unit in the designed parametric pattern. Credits: Erfan Zamanigoldeh 


\subsection{Modules' Size}

This parametric Muqarnas has 5 rows and due to the nature of Muqarnas, each row has its specific components in terms of size. (In the traditional Muqarnas the shapes don't change but size becomes smaller from bottom to top. But in our study, the components' shapes become a little bit different, although the difference is not obvious after assembly). So, this parametric Muqarnas has 5 sets (more levels can be added) of shapes and sizes and modules get heavier and bigger from bottom to top. The number of modules in each row are the same and can be changed parametrically.

\subsection{Backrest}

In this study, each module is transferring the weight of itself and modules above to the modules below. In traditional Muqarnas, particularly in complex and Shirazi types (in Al-Kashi classification), the arcs and triangle shape components can be seen below each mould. Usually, this is known as tile decoration and doesn't have any structural role but in our Muqarnas, it has been inspired for structural consideration. (Figure 8)

Each Muqarnas has two backrests on both sides that provide enough spaces for the two moulds above. In this way, each module is supported by both the side modules and the bottom modules. Also, it could provide an overlap surface between two modules which allows adding more joint for large scale and different materials.

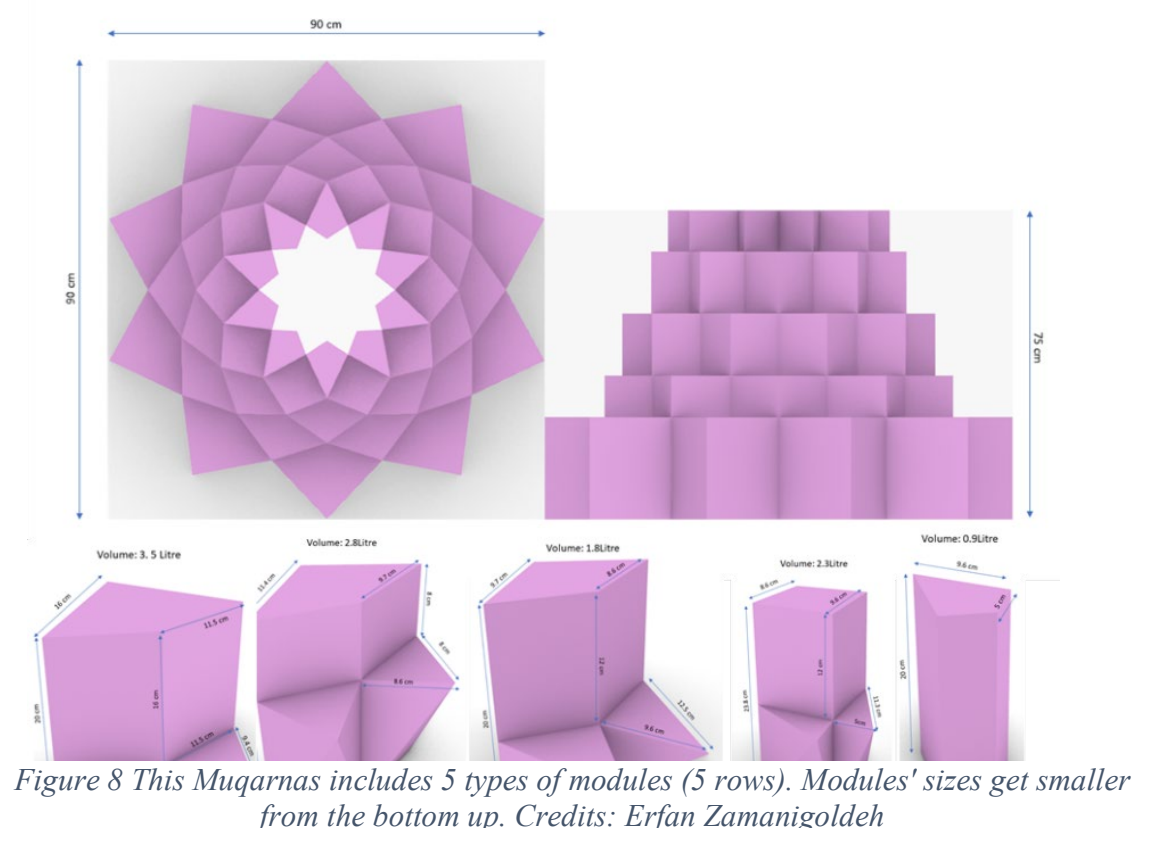




\subsubsection{Parametric Structure}

First, we should start from the components we had in the strategy 11. As we discussed we have two algorithms for two sets of components (5 components in overall). (Figure 9)

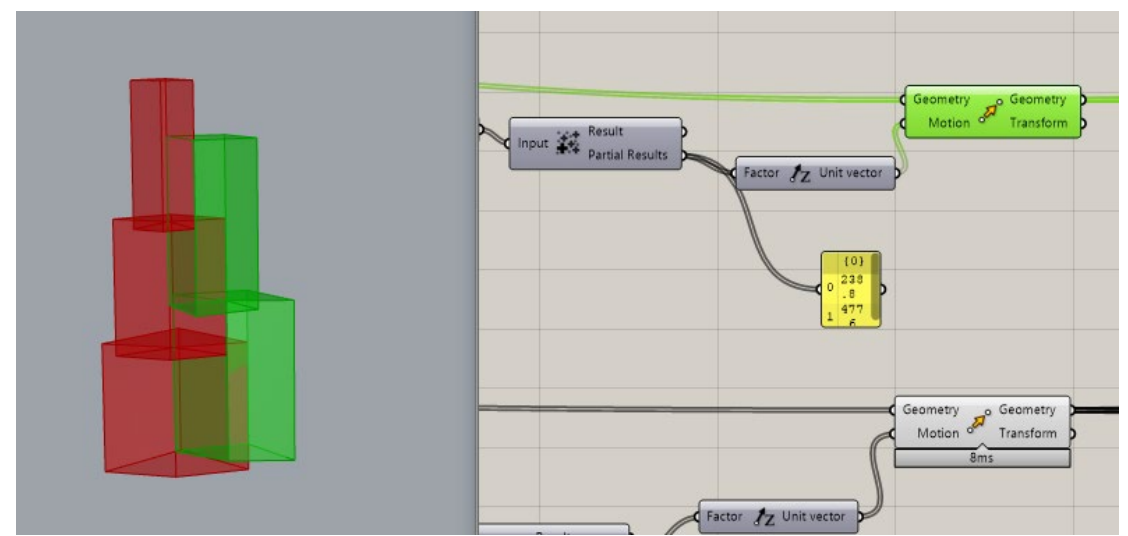

Figure 8 As there are two separated definitions, two separated definitions should be taken for backrest as well. Credits: Erfan Zamanigoldeh

We select one of these sets and dispatch it to get components separately (we can use list item). Same action would be repeated for the other set of components. Then, the components vertices should be extracted, so we use "Deconstruct Brep" for each component. Now, we can see that we have two components with overlap and a free space in the bottom of the first component. Now we shall extract this space as a separated surface. To do so, we use vertices and create a new surface. This surface will play the main role to build backrest of each component. To extrude this surface and make it solid we shall use "extrude to point" and a point of the component in above has been selected. After export, we need this solid on the other side of the component as well. So, we use "mirror" component. (Figure 10)

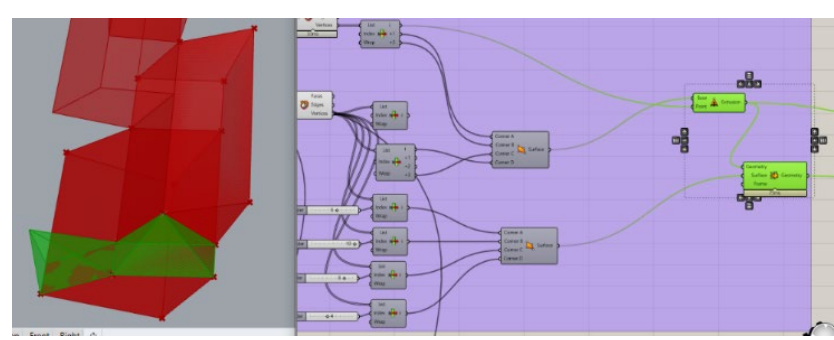

Figure 9 Decoration is used to be as backrest of above components Credits: Erfan Zamanigoldeh 
Now the action would be applied in all components. And then it should be arrayed to have a complete dome.it should be considered that because of Symmetry in 2D pattern plan that we have used, all backrests would be matched perfectly.

\subsection{UAV-based assembly: Proposed Assembly Sketch}

Modules assembly will be carefully analysed in the next part of the research and will be reported in another paper. However, in this paper, a sketch is proposed to be examined under scale. The proposed assembly strategy aims to use a board that the first-row pattern should be carved on it. (Figure 11)
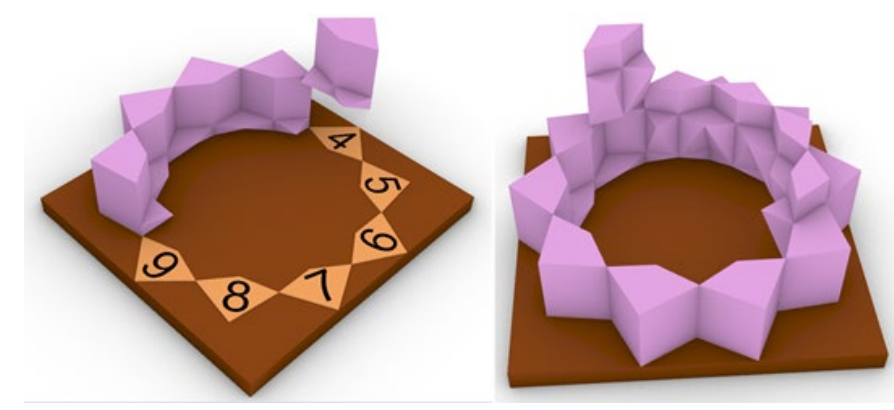

Figure 10 The border of the first row's components would be drawn on a board and programmed UAV will put the first set of components on relevant units. Then, the components will be put on above each other, row by row. Credits: Erfan Zamanigoldeh

The UAV should pick each module from the picking site. In the picking site, components would be placed with the right orientation. Picking site will be helpful to lead the programmed UAVs and minimise the UAV flying distance and rotation. (Figures 12 and 13)

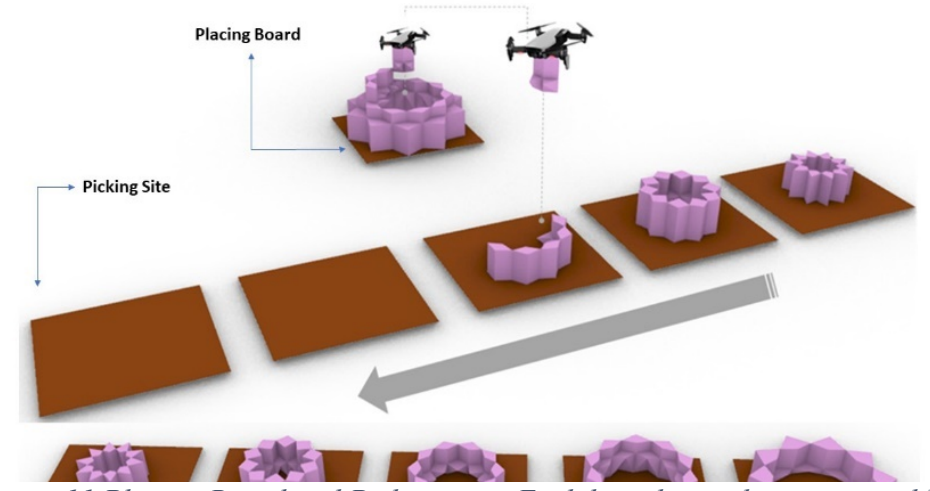

Figure 11 Placing Board and Picking-site: Each board in picking-site would be moved after picking up all its modules. Credits: Erfan Zamanigoldeh 


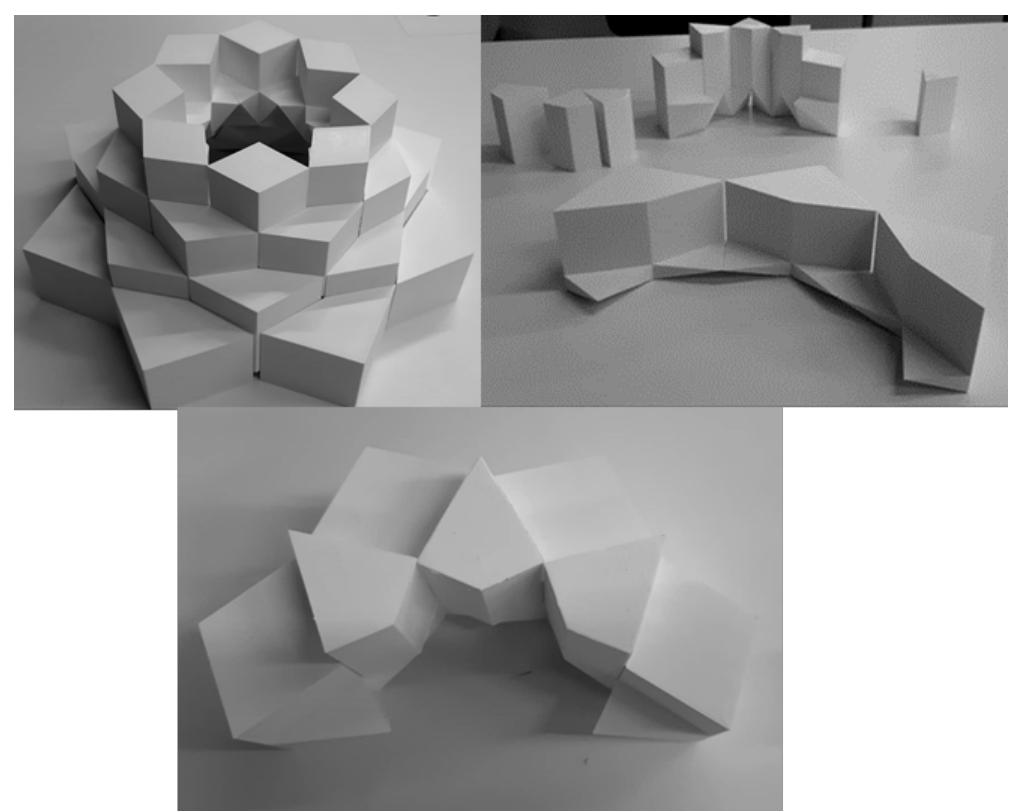

Figure 12 The modules have been 3d-printed under 1/3 scale to test the structure resistance and their assembly. Credits: Erfan Zamanigoldeh

\section{Constraints and Conclusions}

In the first stage, this paper focused mostly on the analysis and extraction parametric features of the Iranian-Islamic Muqarnas and its encoding into a modular system. In the second stage, this paper formulated a parametric generative production and then tested an assembly strategy under the scale.

The parametric algorithm introduced in this paper could generate a diverse variety of designs of Muqarnas. Although Muqarnas traditionally is considered as the decorative element, but this study considers the four main specifications mentioned bellow to define the parametric Muqarnas as a structural element:

1. volume (length, width and height), 2. Scale, 3. algorithm, 4. twodimensional pattern plan.

The main advantage of our method is that all four mentioned specifications can be changed parametrically.

This study analysed generatively the feasibility of the design and production of discrete modular structures, by using the Muqarnas as a basis. The picking and placing technique, from above, would be helpful to generate an assembly model based on UAV. The parametric design causes the modules 
to have a reliable structure. This parametric approach can be potentially expanded to other DfMA strategies.

This experimental DfMA approach can be used with discretization in analytically "disassembling" various other structures that present with the same or similar characteristics. These are the complex geometric definition, the analysis, recognition or use of discrete modular elements, the interlocking of faces and volumes to achieve structural stability, and then the synthesis of the structure by using a pick and assemble technique from above. It is notable that this characteristic assembly does not use any mortar or binder but only uses friction-based forces and the interlocking geometry produced by the careful parametric analysis and generative synthesis.

Also, the proposed methodology of this paper could be used to analyse the vernacular architecture, parametrically. This vernacular synthesis would be helpful to redesign the vernacular architectural shapes and create modular generative systems from them.

\section{Discussion}

Our Modular UAV-based DfMA process is still under development, and we report early results, validated through the hybrid method of developing parametric design strategies and validation through printing the modules and assembly under a scaled model. It has explored in a non-exhaustive manner a traditional architecture as inspiration for a parametric generator of modules for a UAV-based fabrication strategy which is still in development. In the next phase, in addition of introducing new structural simulation and testing, the result of this research would be used for generalizing and expanding discretization and generating parametric architectural modules for assembly out of a range of architectural case studies. The expectation is that after ensuring the strength of the structure (in particular, lateral forces analysis) and efficiency of the assembly model, the assembly via programmed UAVs would be developed to complete our experimentation.

\section{References}

1.Kazempour, H, (2014). Iii, The evolution of muqarnas in Iran from pre-Seljuk to ILKhanid period. [online] Available at: http://eprints.utm.my/id/eprint/78066/1/HamidrezaKazempourfardPFAB2014.pdf.

2.Alaçam, S., Güzelci, O.Z., Gürer, E. and Bacınoğlu, S.Z. (2017). Reconnoitering computational potentials of the vault-like forms: Thinking aloud on muqarnas tectonics. International Journal of Architectural Computing, 15(4), pp.285-303.

3.Govabari, M. and Ghalamara, S. (2018). Analysis of Muqarnas art in historical periods before and after Islam in Iran and the extent of the spread of this art in the world. [online] Tehran: 
Memarishenasi Journal, Number 5. Available at:

http://ensani.ir/file/download/article/1550384077-10149-5-10.pdf.

4. Kashani GADJ. Meftah al Hesab, Revised by Adamerdanes \& Asheikh, Cairo, Dar al Ketab al Arabi Atab va Nashr, 1967. \& Britanisky LS, Rosinfied B. Ghais al din Jamshid Kashani, Azerbaijan Art, 5, 1956.

5.Senhaji, M. and Benslimane, R. (2019). Automatic 3D muqarnas architectural patterns reconstruction using plane representation. Journal of Cultural Heritage, 35, pp.25-40.

6.Yaghan, M.A.J. (2003). Gadrooned-Dome's Muqarnas-Corbel: Analysis and Decoding Historical Drawings. Architectural Science Review, 46(1), pp.69-88.

7.Yaghan, M.A.J. (2000). Decoding the Two-Dimensional Pattern Found at Takht-i Sulayman into Three-Dimensional Muqarnas Forms. Iran, 38, p.77.

8.Yaghan, M.A.J. (2001). The Muqarnas Pre-Designed Erecting Units: Analysis, Definition of the Generic Set of Units, and a System of Unit-Creation as a New Evolutionary Step. Architectural Science Review, 44(3), pp.297-318.

9.Hamekasi, N. (2013). Interactive Design of Muqarnas. prism.ucalgary.ca. [online] Available at: http://hdl.handle.net/11023/441 [Accessed 9 Sep. 2020].

10.Hamekasi, N., Samavati, F.F. and Nasri, A. (2011). Interactive modeling of Muqarnas. Proceedings of the International Symposium on Computational Aesthetics in Graphics, Visualization, and Imaging - CAe ' 11.

11.Kazempour, H., (2016). The Evolution of Muqarnas in Iran. Reseda, La: Supreme Century, pp.7-8.

12.SWINFORD, D. (2019). The Muqarnas: A Key Component of Islamic Architecture | Encyclopedia.com. [online] Encyclopedia.com. Available at: https://www.encyclopedia.com/science/encyclopedias-almanacs-transcripts-andmaps/muqarnas-key-component-islamic-architecture.

13. Mohammadian, S. and Faramarzi, S. (2013). Investigation of the existence of quasi-periodic order in the geometric structure of the Patkaneh. [online] Honar hay-e Ziba Journal (Fine Arts University). Available at: https://jfaup.ut.ac.ir/article_50533_69a27da7b9ae5e4a47fd636e2e38f86a.pdf [Accessed 28 Aug. 2020].

14.Gherardini, F. and Leali, F. (2016). A Framework for 3D Pattern Analysis and Reconstruction of Persian Architectural Elements. Nexus Network Journal, 18(1), pp.133167. 